\title{
ONLINE SADRŽAJI I USLUGE \\ NAMIJENJENI DJECI NA INTERNETSKIM STRANICAMA DJEČJIH KNJIŽNICA U HRVATSKOJ
}

\author{
ONLINE CONTENT AND SERVICES FOR CHILDREN \\ ON WEB PAGES OF CHILDREN LIBRARIES IN CROATIA
}

\author{
Jelena Pavičićc \\ Odsjek za informacijske i komunikacijske znanosti \\ Filozofski fakultet Sveučilišta u Zagrebu \\ jelenapavicic73@gmail.com \\ Radovan Vrana \\ Odsjek za informacijske i komunikacijske znanosti \\ Filozofski fakultet Sveučilišta u Zagrebu \\ rvrana@ffzg.hr
}

UDK / UDC 027.625: 004.738.5(497.5)

Izvorni znanstveni rad / Original scientific paper

Primljeno / Received: 23. 10. 2018.

Prihvaćeno / Accepted: 12. 12. 2018.

\section{Sažetak}

Cilj. Cilj istraživanja u ovome radu bio je utvrditi postojanje sadržaja i usluga namijenjenih isključivo djeci na internetskim stranicama dječjih knjižnica u Hrvatskoj te odgovoriti na sljedeća istraživačka pitanja: postoje li i koje su vrste sadržaja (prema predstavljenom japanskom modelu) dostupne putem internetskih stranica dječjih

1 Članak je nastao na temelju diplomskog rada Jelene Pavičić „Knjižnične usluge za djecu“, napisanog pod mentorskim vodstvom izv. prof. dr. sc. Radovana Vrane i predstavlja njegovu skraćenu i prerađenu verziju. Jelena Pavičić studentica je Diplomskog studija informacijskih znanosti - smjera bibliotekarstvo na Odsjeku za informacijske i komunikacijske znanosti Filozofskog fakulteta Sveučilišta u Zagrebu.

Vjesnik bibliotekara Hrvatske 62, 1(2019), 103-127

ISSN 0507-1925

(C) VBH 2018. 
knjižnica u Hrvatskoj i postoje li i koje su usluge za djecu dostupne putem internetskih stranica dječjih knjižnica u Hrvatskoj?

Pristup/metodologija/dizajn. U ovom je istraživanju provedena analiza online sadržaja internetskih stranica dječjih knjižnica u Hrvatskoj u sklopu svih dostupnih internetskih mjesta (bez iznimaka) narodnih knjižnica u Hrvatskoj. Ustanovljen je ukupan broj od 193 dostupna internetska mjesta narodnih knjižnica. Kriterij odabira internetskih stranica dječjih knjižnica u Hrvatskoj u ukupnom broju dostupnih internetskih mjesta narodnih knjižnica bile su one internetske stranice dječjih knjižnica u Hrvatskoj koje su nedvojbeno nudile online sadržaje i usluge namijenjene djeci, njih ukupno 32. Prilikom analize sadržaja internetskih stranica dječjih knjižnica u Hrvatskoj primijenjen je model CIRRI (Core Information Reference Research Instruction (CIRRI) Contents Model) koji su osmislili Kanazawa, Maruyama i Motoki.

Rezultati. Provedeno istraživanje ukazuje na činjenicu kako u odnosu na ukupan broj narodnih knjižnica u Hrvatskoj ne postoji znatan broj narodnih knjižnica koje na svojim internetskim stranicama nude sadržaje i usluge namijenjene djeci. Od svih dostupnih internetskih mjesta narodnih knjižnica u Hrvatskoj koje su pregledane i analizirane, bilo je moguće izdvojiti njih ukupno 32, a među izdvojene 32 rijetke su bile one internetske stranice dječjih knjižnica u Hrvatskoj koje su sadržajima i uslugama namijenjene isključivo djeci. Mnoge od njih teško je locirati u sklopu internetskih mjesta narodnih knjižnica jer nisu bile vidljivo istaknute, nisu bile redovito ažurirane i često su služile samo kao pokazatelji postojanja dječje knjižnice u prostorima narodne knjižnice te postojanja pojedinih stalnih programa pojedinih narodnih knjižnica za djecu koji se odvijaju u prostoru knjižnice. Rijetke su one internetske stranice dječjih knjižnica u Hrvatskoj za koje se može reći da zadovoljavaju potrebe djece za informacijama, znanjem i zabavom. Analizom sadržaja internetskih stranica dječjih knjižnica u Hrvatskoj moguće je zaključiti kako postoji znatan prostor za napredak u ponudi i organizaciji online sadržaja i online usluga za djecu.

Praktična primjena. Rezultate istraživanja moguće je primijeniti u procesu oblikovanja budućih internetskih stranica narodnih knjižnica uz pomoć primjera postojećih vrsta online sadržaja i online usluga.

Ključne riječi: Hrvatska, internet, narodne knjižnice, sadržaj za djecu, usluge za djecu

\begin{abstract}
Purpose. The purpose of this paper is to establish whether public libraries offer content and services exclusively for children on their Web pages and to answer the following research questions: what online services and what online content for children are available on Web pages of children libraries in Croatia.
\end{abstract}

Approach/methodology/design. An analysis of Web pages of children libraries in all the Croatian public libraries available online (non-existent and non-available Web 
sites of the Croatian public libraries were not researched) was conducted. Out of the total of 193 available public libraries' Web sites, the criterion for selection of public libraries for further analysis was whether those public libraries were offering content and services for children on the Web pages of children libraries; 32 such libraries were identified and selected. The analysis was made by using the CIRRI model (Core Information Reference Research Instruction (CIRRI) Contents Model) designed by Kanazawa, Maruyama, and Motoki.

Findings. The research shows that there are not many public libraries in Croatia that offer content for children on their Web pages. Of all visited and analysed Web pages, only 32 of them were intended to be used by children. Many of them were not regularly updated, they were hard to find on the Web sites of public libraries as they were not specially highlighted and serve only as an indicator of existence of children libraries and some of their permanent activities. Very few Web pages could satisfy the children's needs for information, knowledge, and entertainment. The analysis of the Web pages of the Croatian public libraries indicates that there is still room for significant improvement of the content itself and organization of that content and other resources for children, their parents, and educators.

Practical implications. The results of the research are applicable in the process of design of future Web pages of public libraries using the existing online content and services for children as an example.

Keywords: content for children, Croatia, internet, public libraries, services for children

\section{Uvod}

U IFLA-inim (International Federation of Library Associations and Institutions) smjernicama za narodne knjižnice ističe se kako je jedna od važnih sastavnica djelatnosti knjižnice razvijanje osobne kreativnosti i novih interesa, a posebna je odgovornost u zadovoljavanju potreba djece i mladih. ${ }^{2}$ Stoga je pri planiranju i oblikovanju knjižničnih usluga i sadržaja za djecu u prostorima knjižnica i putem internetskih stranica potrebno imati na umu način komuniciranja djece putem globalne računalne mreže i njihovu potrebu za interaktivnošću te, općenito, njihove želje i potrebe za online sadržajima i uslugama. Zbog važnosti razvoja narodnih knjižnica i osiguravanja njihove budućnosti, narodne knjižnice danas trebaju biti tamo gdje su njihovi korisnici, a oni se sve više nalaze na internetu. ${ }^{3}$ Imajući na umu navedeno, svrha je ovoga članka ukazati na nedostatnu količinu sadržaja i usluga namijenjenih djeci na internetskim stranicama dječjih knjižnica u Hrvatskoj.

2 Usp. IFLA-ine smjernice za narodne knjižnice / uredile Christie Koontz i Barbara Gubbin. Zagreb: Hrvatsko knjižničarsko društvo, 2011.

3 Usp. Stropnik, A. Knjižnica za nove generacije: virtualni sadržaji i usluge za mlade. Zagreb: Hrvatsko knjižničarsko društvo, 2013. 
Uvodni dio članka donosi pojašnjenje pojma i uloge narodne knjižnice, a zatim i dječje knjižnice. U nastavku članka govori se o važnosti prisutnosti online sadržaja i usluga namijenjenih djeci na internetskim stranicama dječjih knjižnica u Hrvatskoj. U zadnjem dijelu članka bit će prikazani rezultati sadržajne analize internetskih stranica dječjih knjižnica u Hrvatskoj.

\section{Narodne knjižnice i izazovi digitalne informacijske okoline}

Narodne knjižnice obavijesna su središta koja svojim korisnicima omogućavaju neposredan pristup različitim vrstama znanja, a njihove se službe temelje na osiguravanju jednakosti pristupa sadržajima i uslugama knjižnice svim članovima društva, bez obzira na njihovu dob, rasu, spol, vjeru, nacionalnost, jezik ili društveni položaj. ${ }^{4}$ Knjižnične usluge moraju biti osigurane građanima bez diskriminiranja, isključivanja, ograničavanja ili davanja prednosti pojedinim društvenim skupinama.

Narodne knjižnice imaju važnu ulogu u poticanju čitanja i promociji opće kulture te u promicanju više vrsta pismenosti poput informacijske pismenosti, digitalne pismenosti, medijske pismenosti, vizualne pismenosti, podatkovne pismenosti, financijske pismenosti, građanske i etičke pismenosti, računalne pismenosti te informiranosti, međukulturnog dijaloga i obrazovanja.

UNESCO-ov Manifest za narodne knjižnice navodi dvanaest točaka u kojima su opisani glavni ciljevi rada narodnih knjižnica: stvaranje i jačanje čitateljskih navika kod djece od rane dobi; podupiranje osobnog obrazovanja za koje se odlučuje pojedinac, kao i formalnog obrazovanja na svim razinama; stvaranje mogućnosti za osobni kreativni razvoj; poticanje mašte i kreativnosti djece i mladih ljudi; promicanje svijesti o kulturnom nasljeđu, uvažavanju umjetnosti, znanstvenih postignuća i inovacija; osiguravanje pristupa kulturnim izvedbama svih izvođačkih umjetnosti; gajenje dijaloga među kulturama i zastupanje kulturnih različitosti; podupiranje usmene tradicije; osiguravanje pristupa građana svim vrstama obavijesti o njihovoj zajednici; pružanje primjerenih obavijesnih službi mjesnim poduzećima, udrugama i interesnim skupinama; olakšavanje razvitka obavijesnih vještina i računalne pismenosti; podupiranje i sudjelovanje u programima razvijanja pismenosti namijenjenima svim dobnim skupinama i iniciranje takvih programa kada je potrebno. ${ }^{5}$ Navedeni ciljevi od narodnih knjižnica zahtijevaju transformaciju i prilagodbu novoj digitalnoj okolini u kojoj korisnici zahtijevaju digitalne sadržaje i online usluge koje mnoge knjižnice u Hrvatskoj još uvijek nemaju.

4 Usp. IFLA-in i UNESCO-ov Manifest za narodne knjižnice. // IFLA-ine smjernice za narodne knjižnice / uredile Christie Koontz i Barbara Gubbin. Zagreb: Hrvatsko knjižničarsko društvo, 2011.

5 Isto. 
Narodne knjižnice susreću se danas s brojnim izazovima poput smanjenja proračuna, integracije informacijske i komunikacijske tehnologije u svoje usluge, shvaćanja potreba korisnika za cjeloživotnim obrazovanjem, a tu su i nove generacije korisnika čije su informacijske i druge potrebe oblikovane novim životnim okolinama uključujući i internet, a koje se moraju reflektirati i na sadržaje i programe u narodnim knjižnicama. Pojavom interneta knjižnice su izgubile dio postojećih i potencijalnih korisnika koji sve više rade od kuće putem interneta i više ne dolaze ili rijetko dolaze u knjižnicu. Zbog toga je potrebno staviti naglasak na razumijevanje informacijskih i drugih potreba korisnika knjižnica u digitalnoj okolini te poboljšati količinu i kvalitetu sadržaja i usluga koji su korisnicima narodnih knjižnica ponuđeni online. Posebno je potrebno naglasiti takvu potrebu za sadržajima i uslugama za djecu i mlade jer su pametni mobilni telefoni novim generacijama knjižničnih korisnika postali glavna sredstva pristupa digitalnim sadržajima $^{6}$, dok je internet postao njihov glavni komunikacijski kanal, što utječe i na stavove i poglede mladih generacija na knjižnice. ${ }^{7}$ Pritom je najistaknutija generacija Z, tj. mladi rođeni tijekom 1990-ih i početkom novog tisućljeća. Njihovu su generaciju odredili internet, globalizacija i multikulturalnost. ${ }^{8}$ Oni imaju sasvim drukčija očekivanja prema pristupu obrazovanju i informacijskim izvorima u odnosu na druge generacije. ${ }^{9}$ Zbog toga su knjižnice suočene s velikim izazova da promijene svoje usluge u 21 . stoljeću.

„Neki od tih izazova povezani su s promjenama u umreženom informacijskom krajoliku u posljednjih nekoliko desetljeća, uključujući i masovnu i izravnu dostupnost informacija bez posredovanja knjižničara; izazovi su povezani s brigom o masovnom opisu velikih količina podataka i trajnim izazovom knjižnici kao mjestu i vječnim pitanjem budućnosti tiska." ${ }^{10}$

Naime, premda narodne knjižnice u Hrvatskoj svoje fondove temelje na tiskanoj građi i izvjesno je da će takva situacija nastaviti postojati i u bliskoj budućnosti, postavlja se pitanje razvoja digitalnih izvora informacija (digitalnih sadržaja) i njihove ponude korisnicima (usluga) koji ih žele i trebaju, a ne mogu ih pronaći u narodnim knjižnicama u Hrvatskoj ili na njihovim internetskim stranicama.

\footnotetext{
6 Usp. Steinmetz, K. Generation Z finds the upside to growing up amid total disruption. // Time 190, 27/28(2017), 66-67.

7 Usp. Mi, J.; F. Nesta. Marketing library services to the Net Generation. // Library Management 27, 6/7(2006), 411-422.

8 Usp. Kantorová, K.; H. Jonášová; J. Panuš; R. Lipka. A study of generation Z from the communication perspective of universities. // Scientific Papers of the University of Pardubice 24, 40(2017), 83-94.

9 Usp. isto.

10 Hahn, J. The internet of things (IoT) and libraries. // Library Technology Reports 53, 1(2017), str. 5.
} 
Narodne knjižnice trebaju iskoristiti svoj dobar položaj u društvu ${ }^{11}$ i privući mlade generacije korisnika jer za to imaju brojne preduvjete, poput činjenice da se smatraju jednima od ustanova koje su rano usvojile upotrebu interneta. ${ }^{12}$ Dodatna je prednost narodnih knjižnica u činjenici da su se već prije razvile u primarni izvor pristupa internetu u mnogim zajednicama i na taj su način svojim uslugama stvorile vrste novih utjecaja u zajednicama u kojima djeluju. ${ }^{13}$ Povezujući mogućnost pristupa internetu u narodnim knjižnicama u Hrvatskoj, rastući broj online sadržaja i usluga na internetskim stranicama narodnih knjižnica u Hrvatskoj (za različite kategorije korisnika) te sklonost mladih generacija da sadržaje i usluge potraže upravo na internetu, narodne knjižnice mogu iskoristiti svoje resurse i znanje u pomaganju svojim korisnicima da pronađu i pristupe kvalitetnim izvorima informacija na internetu, onima koje su oblikovale same narodne knjižnice, ali i brojnim drugim online sadržajima koje je oblikovao netko drugi.

Ovaj je rad usmjeren ka sadržajima i uslugama za djecu na internetskim stranicama dječjih knjižnica u Hrvatskoj, pa će u nastavku rada biti više riječi upravo o navedenoj temi jer su djeca i mladi jedna od posebnih skupina knjižničnih korisnika sa svojim karakteristikama, potrebama i zahtjevima. ${ }^{14}$

\section{Dječje knjižnice u Hrvatskoj}

Pojam dječjih odjela narodnih knjižnica i dječjih knjižnica nije uvijek posve jasan. Prema Rakočević Uvodić

„[d]ječje su knjižnice specijalizirane ustanove kojima je osnovna uloga prikupljanje knjiga namijenjenih djeci te su stoga primarno usredotočene na poticanje čitanja, odnosno davanja na korištenje što raznovrsnije građe koja uključuje tiskane materijale (knjige, časopise, izreske iz novina i časopisa, kataloge, brošure, informativne listiće, postere i sl.) i neknjižnu građu (igračke, audio i video građu, računalne programe, elektroničke igre, virtualnu građu i sl.)". ${ }^{15}$

Definicija koju je ponudila Rakočević Uvodić daje vrlo jasan okvir važnosti uloge dječjih knjižnica u razvoju djece, ali i društva. Poticanje čitanja jedna je od hrvatskih nacionalnih strategija u kojoj rano usvajanje čitanja pozitivno utječe na

11 Usp. Vrana, R.; J. Kovačević. Položaj knjižnice u umreženom društvu. // Vjesnik bibliotekara Hrvatske 53, 3/4(2011), 25-41.

12 Usp. Bertot, J. C.; P. T. Jaeger; E. E. Wahl; K. I. Sigler. Chapter 2: Public libraries and the internet. // Library Technology Reports 47, 6(2011), 7-18.

13 Usp. Bertot, J. C.; C. R. McClure.; P. T. Jaeger. The impacts of free public internet access on public library patrons and communities. // Library Quarterly 78, 3(2008), 285-301.

14 Usp. IFLA-ine smjernice. Nav. dj., str. 43-45.

15 Usp. Rakočević Uvodić, M. Učimo znakovni jezik i kulturu gluhih. // Novi Uvez 27, 2(2017), str. 2. 
uredan dječji razvoj, razumijevanje znanstvenih spoznaja i razvoj govora i jezika u djece predškolske dobi te razvoj učeničkog interesa za istraživački, kritički i kreativni rad putem čitateljskih praksa. ${ }^{16}$

IFLA-ine Smjernice za knjižnične usluge za djecu navode komu su dječje knjižnice namijenjene individualno ili grupno: dojenčadi i maloj djeci; djeci predškolske dobi; djeci školske dobi do trinaeste godine; skupinama djece s posebnim potrebama; roditeljima i drugim članovima obitelji; odgojiteljima i učiteljima; drugim odraslim osobama koje rade s djecom, knjigama i medijima. ${ }^{17}$

Prema The Encyclopedia Americana dječju knjižnicu čine posebne zbirke knjiga namijenjene mladim čitateljima koje su obično dostupne u odvojenom prostoru narodne knjižnice. ${ }^{18}$ Online Dictionary of Library and Information Science nudi sljedeću definiciju dječje knjižnice: prostor u narodnoj knjižnici ili njezinu ogranku rezerviran za zbirke i usluge namijenjene isključivo djeci dobi do 12 ili 13 godina, a u kojima se obično nalazi barem jedan dječji knjižničar i koji je opremljen i može primiti osobe nižeg rasta. ${ }^{19}$

Na temelju navedenog možemo zaključiti kako su knjižnični sadržaji i usluge za djecu obično smješteni u posebnim prostorijama narodnih knjižnica ${ }^{20}$ koje možemo nazivati i dječjim odjelima. U sljedećim poglavljima rada bit će upotrebljavan pojam dječja knjižnica radi veće jasnoće.

Prve dječje knjižnice pojavile su se krajem 19. stoljeća kada su mnoge narodne knjižnice u Americi počele osnivati posebne odjele s knjigama za djecu, ali tek je 1895. izgrađena prva knjižnica s posebno oblikovanom prostorijom za djecu. ${ }^{21}$ Tek je ranih 1900-ih takvo što postalo norma tijekom izgradnje knjižnica.

Prva dječja knjižnica u Hrvatskoj započela je sa svojim radom 16. listopada 1950. u Novinarskom domu, u prostoru bivše male čitaonice Gradske knjižnice u Zagrebu. ${ }^{22} \mathrm{U}$ to vrijeme učenici su činili 70 \% ukupnih članova Gradske knjižnice,

16 Usp. Nacionalna strategija poticanja čitanja za razdoblje od 2017. do 2022. [citirano: 2018-1112]. Dostupno na: https://www.min-kulture.hr/userdocsimages/NAJNOVIJE\%20NOVOSTI/a/ NSPC $\%$ CC $\% 8$ C.pdf.

17 IFLA-ine Smjernice za knjižnične usluge za djecu. [citirano: 2018-12-09]. Dostupno na: http://www.ifla.org/files/assets/libraries-for-children-and-ya/publications/guidelines-for-childrens-libraries-services-hr.pdf.

18 The encyclopedia Americana (1920). Children's libraries. // Wikisource. [citirano: 2018-1202]. Dostupno na:

http://en.wikisource.org/wiki/The_Encyclopedia_Americana_(1920)/Children\%27s_Libraries.

19 Usp. Children's room. // Online Dictionary of Library and Information Science. [citirano:2018-12-02]. Dostupno na: https://www.abc-clio.com/ODLIS/odlis_c.aspx\#childrensroom.

20 Isto.

21 Isto.

22 Usp. Čičko, H. Kako je rastao i razvijao se odjel za djecu i mladež gradske knjižnice. // Dječja knjižnica za novo tisućljeće: zbornik / priredila Ranka Javor. Zagreb: Knjižnice grada Zagreba, 2001. Str. 12-26. 
stoga se javila i potreba za zasebnim prostorom za djecu u narodnoj knjižnici. ${ }^{23}$ Iz cjelokupnog fonda izvučeno je oko 4000 svezaka. Kako je broj upisane djece sve više rastao, 1954. godine prekinuti su upisi kada je dostignut broj od 2000 članova jer nije bilo ni prostora ni mogućnosti da se zadovolji veći broj članova. ${ }^{24}$ U izvještaju iz 1955. godine piše da Dječji odjel ima 10000 knjiga i preko 1000 naslova za sva tri uzrasta (5-8, 8-11 i 11-14 godina), od slikovnica do romana. ${ }^{25}$ Razvoj dječjeg knjižničnog odjela u Zagrebu utjecao je i na ostale narodne knjižnice u Hrvatskoj. ${ }^{26}$ Detaljniji pregled razvoja knjižničnih službi i usluga za djecu u hrvatskim narodnim knjižnicama moguće je pronaći u radu Ivanke Stričević, Hele Čičko i Đurđice Križanić Delač. ${ }^{27}$

Za razliku od prijašnjih vremena, kada su dječje knjižnice ograničavale svoje članstvo samo na djecu koja znaju čitati, a tek su kasnije obuhvatile i predškolsku djecu, danas više nema dobnog ograničenja, štoviše, smatra se poželjnim djetetu čitati još prije navršene prve godine. ${ }^{28}$ Zadaća je dječjih knjižnica osigurati djeci širok izbor građe i programa te pružiti im mogućnost da „osjete radost čitanja i uzbuđenje otkrivanja znanja i djela mašte“ “. ${ }^{29}$ Također, njihova je zadaća podučavati djecu i roditelje kako što bolje iskoristiti mogućnosti koje im pruža narodna knjižnica te razvijati vještine korištenja tiskane i digitalne građe. ${ }^{30}$

Prema IFLA-inim Smjernicama za knjižnične usluge za djecu, ciljevi su rada dječje knjižnice osigurati svakom djetetu pravo na informaciju, funkcionalnu, vizualnu, digitalnu i medijsku pismenost, kulturni razvoj, razvoj vještina i navika čitanja, cjeloživotno učenje, kreativne programe u slobodno vrijeme; svakom djetetu omogućiti slobodan pristup svim izvorima i medijima; organizirati različite programe za djecu, roditelje, odgojitelje i učitelje; omogućiti obiteljima sudjelovanje u životu zajednice; osnaživati djecu i zagovarati njihovu slobodu i sigurnost; ohrabrivati djecu da postanu samopouzdani i sposobni ljudi; zalagati se za mir u svijetu. ${ }^{31}$ Ciljevi dječjih knjižnica obuhvaćaju širok raspon različitih načina zadovoljavanja navedenih potreba svojih korisnika jer djeca kao posebna skupina korisnika knjižnice zahtijevaju posebnu pažnju. Stoga su bitne kvalitetne usluge i programi kojima će se postići navedeni ciljevi.

\footnotetext{
23 Isto, str. 13.

24 Isto, str. 14.

25 Isto, str. 16.

26 Isto.
}

${ }^{27}$ Stričević, I.; H. Čičko.; Đ. Križanić Delač. Knjižnične službe i usluge za djecu u hrvatskim narodnim knjižnicama: razvoj, stanje i perspektive. // Vjesnik bibliotekara Hrvatske 49, 1(2006), 22-36.

${ }^{28}$ Usp. Dječja knjižnica za novo tisućljeće: zbornik / priredila Ranka Javor. Zagreb: Knjižnice grada Zagreba, 2000.

29 Usp. Smjernice za knjižnične usluge za bebe i djecu rane dobi. Zagreb: Hrvatsko knjižničarsko društvo, 2008. Str. 13.

30 Isto. Str. 4.

31 Isto. 


\subsection{Sadržaji i usluge dječjih knjižnica}

Promjenom načina komunikacije i pojavom novih tehnologija promijenile su se i navike djece. Potreba za stjecanjem i razvijanjem kompetencija za cjeloživotno učenje od najranije dobi postala je svakodnevno prisutnom, a multikulturalno okruženje pokrenulo je brojna pitanja o tome tko su danas korisnici knjižnica, postojeći i oni koji to tek trebaju postati. Promijenila se i percepcija dječjih knjižnica pa žarište više nije na knjižnici kao ustanovi, nego na korisnicima i uslugama uz čiju se pomoć zadovoljavaju potrebe korisnika. Knjižnica postoji zbog korisnika i osnovna uloga svake suvremene knjižnice povezana je s promišljanjem odgovora na potrebe djece u složenom društvenom kontekstu ${ }^{32}$ i rastućoj digitalnoj okolini.

Dječje knjižnice danas ne pružaju samo mogućnost čitanja, učenja i pružanja informacija, nego su to mjesta za zabavu i druženje na kojima djeca mogu kreativno i kvalitetno provoditi svoje slobodno vrijeme. Zbog toga bi programi dječjih knjižnica trebali biti raznoliki, kao i građa koja mora biti raznovrsna i primjerena dječjem uzrastu. Općenito, narodna knjižnica mora ponuditi tiskanu građu (knjige, časopise, stripove, brošure), ali i onu neknjižnu, audiovizualnu i digitalnu građu (CD-e, DVD-e), igračke, obrazovne igre, računala, softvere i pristup internetu. ${ }^{33}$ Uz raznolikost, bitno je da građa odražava različite vrijednosti i mišljenja te da odražava kulturu lokalne zajednice. Također, vrlo je važno da se djecu u procesu učenja potiče i na učenje o globalnoj zajednici kroz ponudu građe svjetske književnosti i multimediju. Uz to, građa bi morala biti visokokvalitetna i suvremena kako bi djeca učila u skladu s današnjim tehnološkim razvojem i u svakom trenut$\mathrm{ku}$ išla ukorak sa suvremenim razvojnim nastojanjima. ${ }^{34}$

Narodna knjižnica djeci nudi mjesto koje je oslobođeno školskih pravila i ograničenja roditeljskog doma, a u kojem se učenje slobodno isprepleće s igrom, pritom uključujući sve vrste stvaralaštva i kreativnosti. ${ }^{35}$ Najčešće aktivnosti za djecu i mladež u narodnim knjižnicama jesu: pričaonica ili kutić za najmlađe, likovna radionica, igraonica, grupni posjeti, izložbe, filmske, videoprojekcije i druge projekcije, natjecanja i kvizovi, lutkarske i dramske grupe i igre, lutkarske i glazbeno-scenske predstave, književni susreti i susreti s poznatim osobama, prikazi i predstavljanja novih knjiga, kompjutorske radionice i igre, mali knjižničari, glazbene igraonice i slušaonice, predavanja i tribine, smotre dječje poezije, literarne grupe, sat lektire u knjižnici, razne prigodne akcije ${ }^{36}$, aktivnosti vezane

\footnotetext{
32 Usp. Stričević, I., Knjižnice za djecu u suvremenoj Europi: interkulturalni pristup u multikulturalnom okruženju. // Knjižnica 53, 1-2(2009), 197-208.

33 Leščić, J. Hrvatske narodne knjižnice u godini 2011. // Vjesnik bibliotekara Hrvatske 55, 3/4(2012), 189-216.

34 Usp. Smjernice za knjižnične usluge za djecu. Nav. dj., str. 9.

35 Usp. Dječja knjižnica za novo tisućljeće. Nav. dj.

36 Javor, R. Dječji odjel. // Upute za poslovanje narodnih knjižnica. Zagreb: Knjižnice grada Zagreba, 1996. Str. 93-102.
} 
uz školske obaveze ${ }^{37,38}$, aktivnosti vezane uz provođenje slobodnog vremena za djecu i mlade koji slobodno vrijeme provode sami ${ }^{39}$, razne aktivnosti povezane $\mathrm{s}$ popularizacijom znanosti ${ }^{40}$ itd. Osim programa koji se odvijaju u fizičkim prostorima knjižnice, narodna knjižnica mora ponuditi usluge u online okolini, na svojim internetskim stranicama.

\section{Internetske stranice dječjih knjižnica u Hrvatskoj}

Polazeći od osnovne uloge knjižnica da osiguraju pristup informacijama, kulturi, obrazovanju, učenju i sadržajima koji ispunjavaju slobodno vrijeme, narodne se knjižnice suočavaju s tri problema vezana uz pristup: problem otežanog pristupa, problem motivacije za pristup i problem neograničenog pristupa. ${ }^{41} \mathrm{Za}$ mnogu je djecu pristup knjižnici otežan jer je knjižnica udaljena od mjesta stanovanja, nema za djecu odgovarajuću građu, nije prilagođena potrebama djece invalida, nema odgovarajuće radno vrijeme i sl. Pitanje motivacije za pristup jednako je važan problem. Knjižničari se sve više suočavaju sa smanjenim interesom za čitanje i knjigu i pokušavaju pronaći nove načine kako na čitanje i dolazak u knjižnicu motivirati i one koji ne čitaju i one koji bi čitali kada bi im bilo ponuđeno ono što ih zanima. Unatoč manjku motivacije za čitanje, danas je djeci dostupno više informacija nego ikad, i upravo taj neograničen pristup postaje problem ${ }^{42}$ jer se pojavljuje problem kvalitete dostupnog sadržaja te dobrobiti djece, što dovodi do pitanja kako odgajati i obrazovati nove generacije u obilju informacija kojima su izloženi i među kojima moraju odabrati ono što je najbolje za njih. U tome roditeljima i djeci mogu pomoći internetske stranice dječjih knjižnica.

Internetske stranice dječjih knjižnica imaju svrhu pružiti informacije o samoj fizičkoj knjižnici, osigurati pristup bibliografskim podacima o građi te digitalnoj građi i online uslugama narodne knjižnice čiji su dio. One su za dijete ujedno ,prolaz“ u svijet interneta, bilo da daju upute kako se služiti internetom ili pružanjem zbirke poveznica na korisne i kvalitetne internetske stranice. ${ }^{43}$ Knjižničari putem internetske stranice dječjih knjižnica oblikuju virtualni prostor koji djeci služi kao sigurno polazište u svi-

37 Hands, A. S.; A. Johnson. Lighting the way. // Children \& Libraries: The Journal of the Association for Library Service to Children. 10, 2(2012), 56-57.

38 Out of school and in the library connecting with resources in the out of school time (OST) field. // Young Adult Library Services 9, 4(2011), 10-12.

39 Usp. Stričević, I.; S. Jelušić. Knjižnice usluge za mlade: modeli i koncepti. // Vjesnik bibliotekara Hrvatske 53, 1(2010), 1-34.

40 Hopwood, J. Initiating STEM learning in libraries. // Children \& Libraries: The Journal of the Association for Library Service to Children 10, 2(2012), 53-55.

${ }^{41}$ Usp. Stričević, I. Nav. dj., str. 198-199.

42 Usp. isto, str. 199.

43 Usp. Stričević, I. Internetske stranice knjižnica namijenjene djeci: djeca kao korisnici knjižnice na internetu. // Novi mediji u dječjim knjižnicama / urednik Dunja Holcer. Sisak: Narodna knjižnica i čitaonica, 2008. Str. 6. 
jet interneta na način da osiguravaju kvalitetan, koristan, ali i zanimljiv sadržaj koji je primjeren djeci i putem kojega mogu na sigurniji način istraživati mogućnosti interneta i učiti kako se snaći u obilju informacija koje se na internetu nude.

\subsection{Sadrăaj internetskih stranica dječjih knjižnica u Hrvatskoj}

Sadržaj internetskih stranica dječjih knjižnica namijenjenih isključivo djeci zahtijeva posebnu pažnju pri njihovu oblikovanju. Stvaranje atraktivne i uspješne internetske stranice koja služi djeci uključuje prikladan sadržaj i upotrebljivost koja se odnosi na to da djeca odmah mogu razumjeti koja im je informacija pružena. Pružena informacija pritom mora biti jednostavna za čitanje i razumljiva te mora omogućiti djeci lak dolazak do informacije koja im je potrebna. ${ }^{44}$ Kako bi se stvorila kvalitetna internetska stranica namijenjena djeci, potreban je i prikladan internetski sadržaj. ${ }^{45}$

Kanazawa, Maruyama i Motoki 2011. proveli su istraživanje kojim su analizirali različite vrste sadržaja koji je dostupan na japanskim internetskim stranicama knjižnica namijenjenih djeci pomoću modela CIRRI (Core Information Reference Research Instruction (CIRRI) Contents Model) za sadržaj internetskih stranica (slika 1) ${ }^{46}$ Taj model primarno je nastao u svrhu ispitivanja internetskih stranica školskih knjižnica te je potom primijenjen u ispitivanju internetskih stranica dječjih knjižnica u ovom članku. ${ }^{47}$

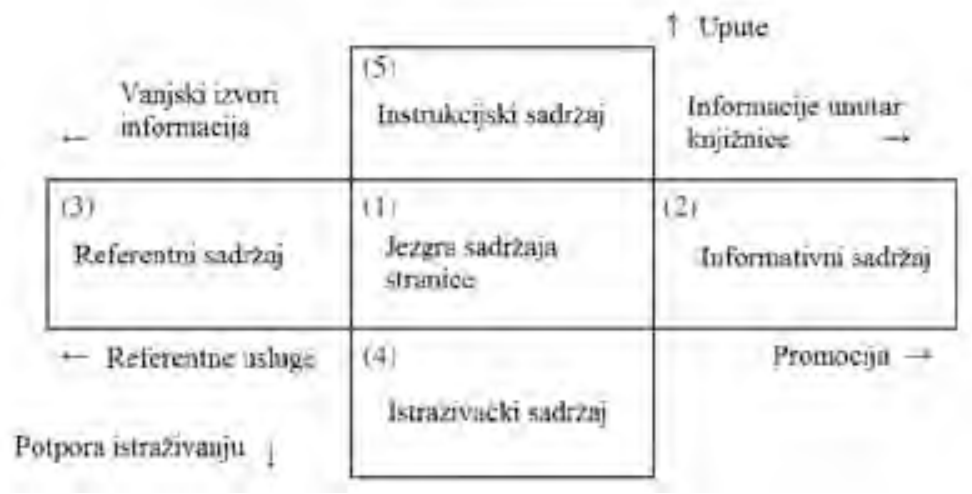

Slika 1. Model sadržaja CIRRI

44 Usp. Kanazawa, M., Maruyama, Y. An Evaluation of Public Library Websites: Describing Children's Services in Japan. // Public Library Quarterly. 27, 4(2008), str. 292.

45 Usp. Kanazawa, M., Maruyama, Y., Motoki, A. An Analysis of Children's Web Pages in Public Library Web Sites in Japan. // Public Library Quaterly, 30, 4 (2011), str. 271.

46 Usp. Kanazawa, M., Maruyama, Y., Motoki, A. Nav. dj., str. 272.

47 Isto. 
Sadržaji internetskih stranica bili su podijeljeni u pet elemenata: jezgra sadržaja stranice (engl. core contents), informativni sadržaj (engl. information tool contents), referentni sadržaj (engl. reference tool contents), istraživački sadržaj (engl. research tool contents) i obrazovni sadržaj (engl. instructional tool contents). Jezgra sadržaja stranice čini središte internetske stranice školske knjižnice koju su autori analizirali. Informativni sadržaj i referentni sadržaj predstavljeni su sa svake strane jezgre stranice i suprotno jedan od drugoga. Dok je informativni sadržaj vezan uz informacije koje su nalaze unutar knjižnice i podupirao je funkciju javne promocije, referentni sadržaji bili su povezani s vanjskim izvorima informacija i osiguravali su referentne usluge. Obrazovni i istraživački sadržaji također su uključeni u model jer je obrazovni sadržaj osiguravao instrukcijske upute za djecu, dok je istraživački sadržaj pružao potporu učiteljima za istraživanje. ${ }^{48}$

U Hrvatskoj je provedeno srodno istraživanje koje se bavilo internetskim stranicama školskih knjižnica i daje smjernice o njihovu sadržaju, što također predstavlja pomoć u oblikovanju internetskih stranica za djecu. ${ }^{49}$

Za potrebe istraživanja internetskih stranica dječjih knjižnica u Hrvatskoj u ovom radu upotrijebljen je model koji su razvili Kanazawa, Maruyama i Motoki. U izvornom istraživanju trojice autora modela istraženi su sadržaji 110 stranica za djecu japanskih knjižnica u kontekstu promicanja čitanja i informacijskog opismenjavanja i uspoređeni su s modelom CIRRI. Od pet elemenata toga modela, sadržaji stranica za djecu analizirani su s obzirom na sljedeća četiri elementa oko jezgre: ${ }^{50}$

1. Informativni sadržaj - osigurava djeci, roditeljima i ostalim odraslim osobama koje rade s djecom informacije o dječjim uslugama u narodnim knjižnicama. U tu vrstu sadržaja ubrajamo upute za korisnike, popise knjiga ili „razgovore o knjizi“, uvjete korištenja, programe za djecu i najnovije informacije o uslugama za djecu.

2. Referentni sadržaji - osiguravaju djeci pristup Web-OPAC-ima, referentnoj građi ili izvorima na internetu. Također sadrže i informacije o tome kako koristiti ovu građu i izvore. Važan su element te vrste sadržaja Web-OPAC-i za djecu, poveznice na opće informacijske izvore na internetu, poveznice na internetske pretraživače i referentne usluge putem elektroničke pošte.

\footnotetext{
48 Usp. isto.

49 Faletar, S.; K. Golub; A. Sudarević. Smjernice za izradu mrežnih stranica školskih knjižnica: usporedba hrvatskih i stranih primjera. // Zbornik radova 14. proljetne škole školskih knjižničara, Crikvenica 2002. / ur. Biserka Šušnjić, Ĉudita Franko, Theodor de Canziani Jakšić. Rijeka: Ministarstvo prosvjete i sporta RH: Zavod za unapređenje školstva: Prva sušačka gimnazija u Rijeci, 2003. Str. 75-88.

50 Usp. Kanazawa, M.; Y. Maruyama; A. Motoki. Nav. dj., str. 274-276.
} 
3. Obrazovni sadržaji - usmjeravaju se na poučavanje informacijske pismenosti i pomažu djeci u učenju iz svih predmeta, odnosno područja. Važni su elementi obrazovnog sadržaja poveznice na informacijske izvore na internetu za stjecanje znanja o određenom predmetu, informacije koje poučavaju djecu o tome kako koristiti knjižnicu, online instrukcije i pomoć oko domaće zadaće.

4. Istraživački sadržaji - osiguravaju odraslim osobama kao što su roditelji, učitelji i odgajatelji informacije o dječjim uslugama, materijalima za čitanje i izvorima. Glavni su elementi tih sadržaja informacije za odrasle o programima za djecu, osnovna znanja o dječjim knjigama i čitanju te informiranje o korištenju knjižnice.

Internetske stranice dječjih knjižnica trebale bi se obraćati djeci (ali i njihovim roditeljima, učiteljima i ostalim odraslim osobama koje rade s djecom) putem sadržaja koji nude, a dostupne informacije ne bi trebale biti usko vezane samo uz usluge i programe koji se odvijaju u fizičkim prostorima knjižnice, već bi trebale uključiti i online referentne usluge i obrazovni sadržaj koji podupire dječju znatiželju, ali i pomaže u rješavanju obveznih školskih zadaća.

\section{Istraživanje - utvrđivanje postojanja online sadržaja i usluga na- mijenjenih djeci na internetskim stranicama dječjih knjižnica u Hrvatskoj}

\subsection{Svrha i cilj istraživanja}

Internetska stranica knjižnice (općenito) ima bitnu ulogu u predstavljanju resursa knjižnice njezinim sadašnjim i budućim korisnicima. Posebnu skupinu korisnika knjižnice čine djeca koja sve više vremena provode na internetu i pritom su izložena raznim vrstama sadržaja, ponekad upitne kvalitete, koje moraju naučiti razlučiti od kvalitetnih izvora. ${ }^{51}$ Stoga knjižnice nastoje ponuditi kvalitetne sadržaje (vlastite i s udaljenih lokacija) i usluge na svojim internetskim stranicama kako bi korisnicima osigurale pristup informacijama za koji se zalažu i time potvrdile svoju ulogu u društvu. ${ }^{52}$ Kada je riječ o sadržajima internetskih stranica narodnih knjižnica namijenjenim djeci, svrha je ovoga rada i istraživanja u njemu ukazati na nedostatnu količinu sadržaja i usluga namijenjenih djeci na internetskim stranicama dječjih knjižnica u Hrvatskoj. Cilj je istraživanja utvrditi postojanje sadr-

51 Usp. Cohen, V. L.; J. E. Cowen. Literacy for children in an information age: teaching reading, writing, and thinking. Australia; Belmont, CA: Wadsworth, 2008.

52 Usp. Cragg, E.; K. Birkwood. Beyond books: what it takes to be a 21st century librarian. // The Guardian, 2011. [citirano: 2018-12-04]. Dostupno na: https://www.theguardian.com/careers/ job-of-21st-century-librarian. 
žaja i usluga za djecu dostupnih u trenutku provedbe istraživanja na internetskim stranicama dječjih knjižnica u Hrvatskoj. Konkretnije, istraživanjem se nastojalo odgovoriti na sljedeća istraživačka pitanja:

1. Postoje li i koje su vrste sadržaja (prema japanskom modelu) dostupne putem internetskih stranica dječjih knjižnica u Hrvatskoj?

2. Postoje li i koje su usluge dostupne putem internetskih stranica dječjih knjižnica u Hrvatskoj?

\subsection{Metodologija istraživanja}

U ovom istraživanju provedena je analiza sadržaja internetskih stranica dječjih knjižnica u Hrvatskoj namijenjenih isključivo djeci, a koja se temeljila na modelu istraživanja japanskih internetskih stranica narodnih knjižnica namijenjenih djeci koje su 2011. godine u Japanu proveli Kanazawa, Maruyama i Motoki ${ }^{53}$ uz pomoć modela CIRRI koji je sadržaj internetskih stranica svrstao u četiri osnovne kategorije: informativni, referentni, obrazovni i istraživački sadržaj. Istovjetne kategorije korištene su i prilikom pregleda internetskih stranica dječjih knjižnica u Hrvatskoj.

Za odabir uzorka pregledane su sve internetske stranice dječjih knjižnica u Hrvatskoj do čijih se internetskih adresa došlo putem Portala narodnih knjižnica u Hrvatskoj. ${ }^{54} \mathrm{Na}$ Portalu su pronađene internetske adrese ukupno 193 narodne knjižnice, od kojih su potom odabrane ukupno 32 knjižnice (prilog 1) koje su na svojim internetskim stranicama imale posebno odvojen i označen sadržaj namijenjen isključivo djeci, a koji je bio odvojen od ostalog sadržaja internetskih stranica dječjih knjižnica u Hrvatskoj i koji je povezan s uslugama i sadržajima za djecu i naslovljen kao Dječji odjel, Za djecu i mlade, Za djecu i roditelje, Dječji kutak, Dječja knjižnica. Istraživanje je provedeno u lipnju 2018. godine posjetom svim internetskim stranicama dječjih knjižnica u Hrvatskoj ${ }^{55}$, na kojima su detaljno pregledani svi dostupni online sadržaji i sve dostupne online usluge namijenjene djeci.

\subsection{Rezultati istraživanja}

Rezultati istraživanja pokazali su kako su sve internetske stranice za djecu imale jedan ili više sadržaja iz kategorija modela CIRRI (vidi tablicu 1).

\footnotetext{
53 Kanazawa, M., Maruyama, Y., Motoki, A. Nav. dj.

54 Knjižnica.hr - portal narodnih knjižnica. [citirano: 2018-01-07]. Dostupno na: http://www. knjiznica.hr/.

55 Kako bi se izbjeglo ponavljanje, u daljnjem tekstu, kada se govori o knjižnicama, uvijek se misli na narodne knjižnice.
} 
Tablica 1. Vrsta sadržaja namijenjenog djeci na internetskim stranicama dječjih knjižnica u Hrvatskoj

\begin{tabular}{|l|c|}
\hline Vrsta sadržaja & Broj internetskih stranica (\%) \\
\hline Informativni & $32(100)$ \\
\hline Referentni & $8(25)$ \\
\hline Obrazovni & $10(31.25)$ \\
\hline Istraživački & $8(25)$ \\
\hline Ukupno & $32(100)$ \\
\hline
\end{tabular}

\subsubsection{Informativni sadržaj}

Elementi informativnog sadržaja prisutni su na svim istraženim internetskim stranicama dječjih knjižnica u Hrvatskoj. Opće informacije o knjižnici koje čine informacije o prostoru, radnom vremenu, osoblju i sl. postoje na 25 internetskih stranica dječjih knjižnica u Hrvatskoj. Uvjeti korištenja usluga narodne knjižnice koji se odnose na informacije o posudbi, kašnjenju i cijeni usluga nalaze se na internetskim stranicama 11 dječjih knjižnica u Hrvatskoj. Razni popisi koje čine top-liste knjiga koje su odabrane za pojedini mjesec, najčitanije knjige, preporuke za čitanje, gledanje, popisi nove građe, tematski popisi i sl. nalaze se na 18 internetskih stranica dječjih knjižnica u Hrvatskoj.

Obavijesti o programima za djecu analizirane su s obzirom na to jesu li potpune ili djelomične. Potpune obavijesti odnose se na internetske stranice sa sadržajem namijenjenim djeci koje u potpunosti prikazuju programe za djecu i imaju kalendar aktivnosti u programima, dok su pod djelomične obavijesti svrstane one knjižnice koje na stranicama sa sadržajem namijenjenim djeci ne prikazuju u potpunosti sve informacije o programima za djecu. Drugim riječima, na internetskim stranicama dječjih knjižnica u Hrvatskoj prikazane su primjerice stalne aktivnosti ili samo aktualne aktivnosti u programima za djecu i nema jasno označenih poveznica na sve obavijesti ili kalendar aktivnosti. Potpune obavijesti ima 12 internetskih stranica dječjih knjižnica u Hrvatskoj, dok djelomične obavijesti ima 9 internetskih stranica dječjih knjižnica u Hrvatskoj. Prema tome, na 11 internetskih stranica dječjih knjižnica u Hrvatskoj ne postoje obavijesti o programima za djecu. 
Tablica 2. Prisutnost informativnog sadržaja na internetskim stranicama dječjih knjižnica u Hrvatskoj

\begin{tabular}{|c|c|c|}
\hline Informativni sadržaj & \multicolumn{2}{|c|}{ Internetske stranice } \\
\hline $\begin{array}{l}\text { Opće informacije o knjižnici (o prostoru, } \\
\text { radnom vremenu, knjižničnom fondu, osoblju } \\
\text { i sl.) }\end{array}$ & \multicolumn{2}{|c|}{25} \\
\hline Uvjeti korištenja usluga knjižnica & \multicolumn{2}{|c|}{11} \\
\hline $\begin{array}{l}\text { Popisi (top-liste knjiga, najčitanije knjige, } \\
\text { preporuke za čitanje, gledanje, noviteti i sl.) }\end{array}$ & \multicolumn{2}{|c|}{18} \\
\hline \multirow{2}{*}{ Obavijesti o programima za djecu } & Potpune & 12 \\
\hline & Djelomične & 9 \\
\hline
\end{tabular}

\subsubsection{Referentni sadržaj}

Referentni sadržaj najmanje je prisutan na internetskim stranicama dječjih knjižnica u Hrvatskoj. Knjižnični katalozi za djecu gotovo i ne postoje. Od svih analiziranih internetskih stranica dječjih knjižnica u Hrvatskoj namijenjenih djeci, samo su Knjižnice grada Zagreba imale knjižnični katalog za djecu i mladež. Unatoč tomu, vizualno oblikovanje tog kataloga nije prilagođeno djeci te se značajno ne razlikuje od onoga namijenjenog odraslima. Uz to, poveznice na internetske pretraživače također su prisutne na jednoj internetskoj stranici dječjih knjižnica u Hrvatskoj.

Tablica 3. Prisutnost referentnog sadržaja na internetskim stranicama dječjih knjižnica u Hrvatskoj

\begin{tabular}{|c|c|}
\hline Referentni sadržaj & Internetske stranice \\
\hline Knjižnični katalozi za djecu & 1 \\
\hline Poveznice na internetske pretraživače & 1 \\
\hline Usluga „Pitajte knjižničare“ & 5 \\
\hline Poveznica na uslugu „Pitajte knjižničare“ & 2 \\
\hline Poveznica na online enciklopedije i rječnike & 5 \\
\hline
\end{tabular}


Pet narodnih knjižnica koje sudjeluju u projektu „Pitajte knjižničare“ na svojim internetskim stranicama dječjih knjižnica u Hrvatskoj nudi sadržaj namijenjen djeci, dok u ostalim narodnim knjižnicama koje ne sudjeluju u projektu poveznicu na internetskim stranicama imaju dvije narodne knjižnice, tj. njihove dječje knjižnice. Poveznice na online enciklopedije pronađene su na internetskim stranicama pet narodnih knjižnica.

\subsubsection{Obrazovni sadržaj}

Obrazovni sadržaj prvenstveno je namijenjen djeci kao podrška učenju i obrazovanju, ali i neformalnom učenju u slobodno vrijeme. Poveznice na internetske izvore za učenje pojedinih školskih predmeta prisutne su na 5 internetskih stranica dječjih knjižnica u Hrvatskoj. Upute kako koristiti knjižnicu, npr. kako posuđivati ili kakva je organizacija građe u knjižnici, nisu toliko prisutne, no ipak 5 internetskih stranica dječjih knjižnica u Hrvatskoj ima takve naputke i objašnjenja.

Pomoć oko učenja i pisanja zadaće imaju 3 internetske stranice dječjih knjižnica u Hrvatskoj. U Knjižnicama grada Zagreba pomoć oko zadaće čine savjeti kako uspješno napisati referat ili zadaću, na stranicama Knjižnice i čitaonice „Fran Galović" Koprivnica te na stranicama Gradske knjižnice Valpovo pomoć u učenju čine poveznice na stranice s korisnim izvorima znanja i alate kao što je primjerice alat za izradu mentalnih (umnih) mapa.

Tablica 4. Prisutnost obrazovnog sadržaja na internetskim stranicama dječjih knjižnica u Hrvatskoj

\begin{tabular}{|c|c|}
\hline Obrazovni sadržaj & Internetske stranice \\
\hline $\begin{array}{c}\text { Poveznice na internetske izvore za učenje pojedi- } \\
\text { nog školskog predmeta }\end{array}$ & 3 \\
\hline Upute kako koristiti knjižnicu & 5 \\
\hline Pomoć oko učenja i zadaće & 5 \\
\hline Poveznice na opće izvore znanja & 2 \\
\hline Zabava & 5 \\
\hline Online čitateljski klubovi i blogovi & 4 \\
\hline Digitalizirana građa za djecu & 2 \\
\hline Poveznice na e-knjige, audioknjige & 5 \\
\hline
\end{tabular}


Poveznice na opće izvore znanja kao što su obrazovni i znanstveni portali ili časopisi nudi 5 internetskih stranica dječjih knjižnica u Hrvatskoj. Zabavni sadržaj i poveznice na stranice sa zabavnim sadržajem prisutne su na 2 internetske stranice dječjih knjižnica u Hrvatskoj. Obje internetske stranice imale su poveznice na online igre i internetske portale sa zabavnim sadržajem namijenjenim djeci, dok je samo jedna internetska stranica nudila sadržaj s kvizovima i videosadržajem poput animiranih filmova i filmova za djecu.

Online čitateljski klubovi i blogovi prisutni su na 5 internetskih stranica dječjih knjižnica u Hrvatskoj. Radi se o čitateljskom blogu „Tragači“, koji su osnovali knjižničari Gradske knjižnice Zadar, Gradske knjižnice Rijeka i Narodne knjižnice „Petar Preradović“ Bjelovar. ${ }^{56} \mathrm{Na}$ stranicama Knjižnica grada Zagreba postoji i poveznica na čitateljski klub Knjigotron u Dječjoj knjižnici Marina Držića, ali na temelju pregleda internetske stranice čini se da ona nije redovito održavana. ${ }^{57} \mathrm{Di}-$ gitaliziranu građu za djecu koju čini dio slikovnica iz fonda knjižnice ili slikovnice koje su radila djeca sadrže 4 internetske stranice dječjih knjižnica u Hrvatskoj. Samo 2 internetske stranice dječjih knjižnica u Hrvatskoj nude poveznice na internetske stranice s besplatnim e-knjigama, a to su portal eLektire ${ }^{58}$ kojemu svaki učenik može pristupiti sa svojim AAI@Edu.HR digitalnim identitetom i stranica International Children's Digital Library ${ }^{59}$ koja je slobodno dostupna.

\subsubsection{Istraživački sadržaj}

Istraživački sadržaj odnosi se na sadržaj koji je namijenjen odraslima kao što su roditelji, učitelji, odgajatelji i svima ostalima čiji je rad i život vezan uz djecu i koji osigurava odraslim osobama informacije o dječjim uslugama, materijalima za čitanje i izvorima. U tablici 5 prikazana je prisutnost istraživačkog sadržaja na internetskim stranicama dječjih knjižnica u Hrvatskoj. Obrazovno-pedagoški izvori za odrasle mogu se naći na 4 internetske stranice dječjih knjižnica u Hrvatskoj. Ti izvori podrazumijevaju sadržaj koji je vezan uz pomoć u odgoju i obrazovanju djece, npr. popis logopedske stručne literature i igara za razvoj grafomotorike, literatura za rad s darovitom djecom, upute kako prepoznati disleksiju i knjige za lako čitanje, zbirke preporučenih stranica o odgoju i obrazovanju djeteta i sl. Vodiči za odrasle o dječjim knjigama i čitanju prisutni su kod osam knjižnica. Takav sadržaj ističe važnost čitanja za razvoj djece i zašto čitati djeci, a na hrvatskim stranicama najčešće je prisutan u obliku promicanja kampanje „Čitaj mi!“60 koja potiče čitanje naglas djeci od rođenja.

\footnotetext{
56 Štivić, V. Tragači u dobrim knjigama i dobrom društvu. // Hrvatsko knjižničarsko društvo. 2012. [citirano: 2018-04-27]. Dostupno na: https://www.hkdrustvo.hr/hkdnovosti/clanak/531.

57 Knjigotron. [citirano: 2018-01-07]. Dostupno na: http://knjigotron.org/klub/\#.

58 eLektire. [citirano: 2018-01-07]. Dostupno na: https://lektire.skole.hr/.

59 International Children's Digital Library. [citirano: 2018-01-07]. Dostupnon na: http://en.childrenslibrary.org/.

60 Čitaj mi! [citirano: 2018-01-07]. Dostupno na: http://www.citajmi.info/naslovna/.
} 
Tablica 5. Prisutnost istraživačkog sadržaja na internetskim stranicama dječjih knjižnica u Hrvatskoj

\begin{tabular}{|c|c|}
\hline Istraživački sadržaj & Internetske stranice \\
\hline Obrazovno-pedagoški izvori za odrasle & 4 \\
\hline Vodiči za odrasle o dječjim knjigama i čitanju & 8 \\
\hline Upute kako koristiti knjižnicu i učiti s djecom & 4 \\
\hline Sigurnost na internetu & 4 \\
\hline
\end{tabular}

Upute kako koristiti knjižnicu i učiti s djecom prisutne su na internetskim stranicama 4 dječje knjižnice u Hrvatskoj. Sadržaj koji informira roditelje o sigurnosti na internetu i tome kako zaštiti djecu od opasnosti na internetu nalazi se na 4 internetske stranice dječjih knjižnica u Hrvatskoj.

\subsection{Rasprava i zaključak}

Provedeno istraživanje ukazuje na činjenicu kako u Hrvatskoj ne postoji značajniji broj narodnih knjižnica koje na internetskim stranicama svojih dječjih knjižnica imaju sadržaj i usluge namijenjene isključivo djeci. Od svih dostupnih i pregledanih internetskih stranica dječjih knjižnica u Hrvatskoj, moguće je izdvojiti samo njih 32 (prilog 1). Takav rezultat ukazuje na nedostatan broj online sadržaja i usluga za djecu u narodnim knjižnicama u Hrvatskoj. Pojedine internetske stranice dječjih knjižnica u narodnim knjižnicama nisu u cijelosti prilagođene potrebama djece, mnoge od njih nisu redovito ažurirane, a potrebno je i uložiti priličan trud kako bi ih se našlo u sklopu internetskih mjesta narodnih knjižnica jer nisu vidljivo istaknute ili prikladno izdvojene te često služe samo kao pokazatelji postojanja dječje knjižnice u prostorima narodne knjižnice.

Rezultati istraživanja pokazali su kako je referentni sadržaj prisutan kod najmanjeg broja svih dječjih odjela i dječjih knjižnica u Hrvatskoj. Treba istaknuti kako rezultati vezani uz referentne sadržaje ne ukazuju na to da narodne knjižnice na svojim internetskim stranicama uopće ne nude referentne usluge i sadržaj, već da takav sadržaj nije postavljen na internetskim stranicama namijenjenim djeci.

Što se tiče istraživačkog sadržaja, vrlo malen broj internetskih stranica dječjih knjižnica u Hrvatskoj nudi sadržaje i poveznice na izvore te vrste, njih 8. Najviše je onih koje pružaju izvore o dječjoj knjizi i čitanju, i to promocijom kampanje 
„Čitaj mi!““ ${ }^{61}$ Unatoč tomu što ih je najviše, taj broj nije tako velik, pa od 32 internetske stranice dječjih knjižnica u Hrvatskoj samo njih 8 nudi informacije o toj kampanji.

Potencijal obrazovnog sadržaja kojim narodna knjižnica može pružiti podršku djeci u učenju i informacijskom opismenjivanju nije najbolje iskorišten na većini internetskih stranica dječjih knjižnica u Hrvatskoj. Nešto manje od pola $\mathrm{u}$ istraživanju izdvojenih narodnih knjižnica na svojim internetskim stranicama dječjih knjižnica nudi neke elemente sadržaja obrazovnog karaktera. Kvalitetna pomoć za učenje i domaće zadaće, organizacija izvora za pojedine predmete i zabavni sadržaj kao što su online igre, kvizovi i zabavni internetski portali gotovo da ni ne postoje. Rijetke narodne knjižnice na svojim su internetskim stranicama dječjih knjižnica ponudile razne izvore na hrvatskom jeziku koji mogu pomoći učenicima u pisanju domaćih zadaća i učenju. Na internetskim stranicama dječjih knjižnica u Hrvatskoj, osim eLektira, nema drugih naznaka o dječjoj e-knjizi.

Općenito gledajući, internetske stranice dječjih knjižnica u Hrvatskoj veći naglasak stavljaju na osiguravanje informacija o uslugama knjižnice u njezinu fizičkom prostoru nego na osiguravanju konkretnih sadržaja i usluga namijenjenih isključivo djeci putem svojih internetskih stranica. Najviše internetskih stranica dječjih knjižnica u Hrvatskoj posjeduje elemente informativnog sadržaja. Najviše su usmjerene na osiguravanje općih informacija o knjižnici - o prostoru knjižnice, radnom vremenu, knjižničnom fondu, osoblju i sl. Osim toga, značajan broj istraženih internetskih stranica narodnih knjižnica ne osigurava potpune informacije o aktualnim programima za djecu, već samo stalne programe ili prošle programe pa korisnici, trenutni ili budući, ne mogu dobiti stvarnu sliku o programima knjižnice. Iz toga slijedi prikaz programa za djecu u narodnoj knjižnici koji možda nije istovjetan stvarnoj situaciji u knjižnici, ali nam pokazuje kako se internetske stranice dječjih knjižnica u Hrvatskoj predstavljaju u online svijetu. Ova analiza internetskih stranica dječjih knjižnica u Hrvatskoj važna je za sve postojeće, ali i nove, korisnike sadržaja i usluga narodnih knjižnica jer internetska stranica narodne knjižnice (s obzirom na manjak online sadržaja i usluga) može biti polazna točka za korisnikov posjet knjižnici i istraživanje njezinih izvora i usluga te ga prema tome može odbiti ili privući. Na temelju analize sadržaja internetskih stranica dječjih knjižnica u sklopu internetskih mjesta narodnih knjižnica u Hrvatskoj može se zaključiti kako postoji znatna mogućnost poboljšanja u količini ponude online sadržaja, a posebno online usluga namijenjenih djeci.

61 Isto. 


\section{LITERATURA}

Bertot, J. C.; C. R. McClure; P. T. Jaeger. The impacts of free public internet access on public library patrons and communities. // Library Quarterly 78, 3(2008), 285-301.

Children's room. // Online Dictionary of Library and Information Science. [citirano: 2018-12-02]. Dostupno na: https://www.abc-clio.com/ODLIS/odlis_c.aspx\#childrensroom.

Cohen, V. L.; J. E. Cowen. Literacy for children in an information age: teaching reading, writing, and thinking. Australia ; Belmont, CA : Wadsworth, 2008.

Cragg, E.; K. Birkwood. Beyond books: what it takes to be a 21 st century librarian. // The Guardian, 2011. [citirano: 2018-12-04]. Dostupno na: https://www.theguardian. com/careers/job-of-21st-century-librarian.

Čičko, H. Kako je rastao i razvijao se odjel za djecu i mladež gradske knjižnice. // Dječja knjižnica za novo tisućljeće: zbornik / priredila Ranka Javor. Zagreb: Knjižnice grada Zagreba, 2001. Str. 12-26.

Čitaj mi! [citirano: 2018-01-07]. Dostupno na: http://www.citajmi.info/naslovna/.

Dječja knjižnica za novo tisućljeće: zbornik / priredila Ranka Javor. Zagreb: Knjižnice grada Zagreba, 2000.

eLektire. [citirano: 2018-01-07]. Dostupno na: https://lektire.skole.hr/.

The encyclopedia Americana (1920). Children's 'libraries. // Wikisource. [citirano: 2018-12-02]. Dostupno na: http://en.wikisource.org/wiki/The_Encyclopedia_Americana_(1920)/Children\%27s_Libraries.

Faletar, S.; K. Golub; A. Sudarević. Smjernice za izradu mrežnih stranica školskih knjižnica: usporedba hrvatskih i stranih primjera. // Zbornik radova 14. proljetne škole školskih knjižničara, Crikvenica 2002. / ur. Biserka Šušnjić, Ĉudita Franko, Theodor de Canziani Jakšić. Rijeka: Ministarstvo prosvjete i sporta RH: Zavod za unapređenje školstva: Prva sušačka gimnazija u Rijeci, 2003. Str. 75-88.

Hahn, J. The internet of things (IoT) and libraries. // Library Technology Reports 53, 1(2017), 5-8.

Hands, A. S.; A. Johnson. Lighting the way. // Children \& Libraries: The Journal of the Association for Library Service to Children 10, 2(2012), 56-57.

Hopwood, J. Initiating STEM learning in libraries. // Children \& Libraries: The Journal of the Association for Library Service to Children 10, 2(2012), 53-55.

IFLA-ine Smjernice za knjižnične usluge za djecu. [citirano: 2018-12-09]. Dostupno na: http:/www.ifla.org/files/assets/libraries-for-children-and-ya/publications/guidelines-for-childrens-libraries-services-hr.pdf.

IFLA-ine smjernice za narodne knjižnice / uredile Christie Koontz i Barbara Gubbin. Zagreb: Hrvatsko knjižničarsko društvo, 2011. 
IFLA-in i UNESCO-ov Manifest za narodne knjižnice. // IFLA-ine smjernice za narodne knjižnice / uredile Christie Koontz i Barbara Gubbin. Zagreb : Hrvatsko knjižničarsko društvo, 2011. Str. 105-107.

International Children's Digital Library. [citirano: 2018-01-07]. Dostupno na: http://en. childrenslibrary.org/.

Javor, R. Dječji odjel. // Upute za poslovanje narodnih knjižnica. Zagreb: Knjižnice grada Zagreba, 1996. Str. 93-102.

Kanazawa, M.; Y. Maruyama. An evaluation of public library websites: describing children's services in Japan. // Public Library Quarterly 27, 4(2008), 291-310.

Kanazawa, M.; Y. Maruyama; A. Motoki. An analysis of children's web pages in public library web sites in Japan. // Public Library Quaterly 30, 4 (2011), 270-285.

Kantorová, K.; H. Jonášová; J. Panuš; R. Lipka. A study of generation Z from the communication perspective of universities. // Scientific Papers of the University of Pardubice 24, 40(2017), 83-94.

Knjigotron. [citirano: 2018-01-07]. Dostupno na: http://knjigotron.org/klub/\#.

Knjižnica.hr - portal narodnih knjižnica. [citirano: 2018-01-07]. Dostupno na: http:// www.knjiznica.hr/.

Leščić, J. Hrvatske narodne knjižnice u godini 2011. // Vjesnik bibliotekara Hrvatske 55, 3/4(2012), 189-216.

Mi, J.; F. Nesta; Marketing library services to the Net Generation. // Library Management. 27, 6/7(2006), 411-422.

Nacionalna strategija poticanja čitanja za razdbolje od 2017. do 2022. [citirano: 201811-12]. Dostupno na: https://www.min-kulture.hr/userdocsimages/NAJNOVIJE\%20NOVOSTI/a/NSPC \%CC\%8C.pdf.

Out of school and in the library connecting with resources in the out of school time (OST) field. // Young Adult Library Services 9, 4(2011), 10-12.

Rakočević Uvodić, M. Učimo znakovni jezik i kulturu gluhih. // Novi Uvez. 27, 2(2017), 2-4.

Smjernice za knjižnične usluge za bebe i djecu rane dobi. Zagreb: Hrvatsko knjižničarsko društvo, 2008.

Smjernice za knjižnične usluge za djecu. Zagreb: Hrvatsko knjižničarsko društvo, 2004.

Steinmetz, K. Generation $\mathrm{Z}$ finds the upside to growing up amid total disruption. // Time 190, 27/28(2017), 66-67.

Stropnik, A. Knjižnica za nove generacije: virtualni sadržaji i usluge za mlade. Zagreb: Hrvatsko knjižničarsko društvo, 2013.

Stričević, I. Internetske stranice knjižnica namijenjene djeci: djeca kao korisnici knjižnice na internetu. // Novi mediji u dječjim knjižnicama / urednik Dunja Holcer. Sisak: Narodna knjižnica i čitaonica, 2008. Str. 5-12. 
Stričević, I. Knjižnice za djecu u suvremenoj Europi: interkulturalni pristup u multikulturalnom okruženju. // Knjižnica 53, 1/2(2009), 197-208.

Stričević, I.; H. Čičko; Đ. Križanić Delač. Knjižnične službe i usluge za djecu u hrvatskim narodnim knjižnicama: razvoj, stanje i perspektive. // Vjesnik bibliotekara Hrvatske 49, 1(2006), 22-36.

Stričević, I.; S. Jelušić. Knjižnice usluge za mlade: modeli i koncepti. // Vjesnik bibliotekara Hrvatske 53, 1(2010), 1-34.

Štivić, V. Tragači u dobrim knjigama i dobrom društvu. // Hrvatsko knjižničarsko društvo. 2012. [citirano: 2018-01-07]. Dostupno na: https://www.hkdrustvo.hr/hkdnovosti/clanak/531.

Vrana, R.; J. Kovačević. Položaj knjižnice u umreženom društvu. // Vjesnik bibliotekara Hrvatske 53, 3/4(2011), 25-41. 


\section{Prilozi}

Prilog 1. Popis hrvatskih narodnih knjižnica sa sadržajima za djecu na internetskim stranicama knjižnice

\begin{tabular}{|c|c|c|}
\hline & Naziv knjižnice & $\begin{array}{l}\text { Internetska adresa sadržaja za djecu narodnih } \\
\text { knjižnica u Hrvatskoj }\end{array}$ \\
\hline 1. & $\begin{array}{l}\text { Knjižnice grada } \\
\text { Zagreba }\end{array}$ & http://www.kgz.hr/hr/za-djecu-i-roditelje-4293/4293 \\
\hline 2. & $\begin{array}{l}\text { Knjižnica Nikola } \\
\text { Zrinski Čakovec }\end{array}$ & http://www.kcc.hr/djecji-odjel/ \\
\hline 3. & $\begin{array}{l}\text { Knjižnica i čitaonica } \\
\text { grada Preloga }\end{array}$ & http://knjiznica-prelog.webs.com/odjeli \\
\hline 4. & $\begin{array}{l}\text { Gradska knjižnica } \\
\text { Đurđevac }\end{array}$ & $\begin{array}{l}\text { https://knjiznica-djurdjevac.hr/o-knjiznici/dje- } \\
\text { cji-odjel/ }\end{array}$ \\
\hline 5. & $\begin{array}{l}\text { Knjižnica i čitaonica } \\
\text { „Fran Galović““ } \\
\text { Koprivnica }\end{array}$ & $\begin{array}{l}\text { http://www.knjiznica-koprivnica.hr/knjiznica/defaul- } \\
\text { tcont.asp?id=37\&n=3\&side }=1\end{array}$ \\
\hline 6. & $\begin{array}{l}\text { Gradska knjižnica } \\
\text { Krapina }\end{array}$ & http://www.gkkr.hr/index.php/odjelzadjecu \\
\hline 7. & $\begin{array}{l}\text { Gradska knjižnica Dugo } \\
\text { Selo }\end{array}$ & http://gkds.hr/category/djecji-odjel/ \\
\hline 8. & $\begin{array}{l}\text { Gradska knjižnica } \\
\text { Velika Gorica }\end{array}$ & $\begin{array}{l}\text { http://www.knjiznica-vg.hr/djecji-odjel/preporucuje- } \\
\text { mo-vam/ }\end{array}$ \\
\hline 9. & $\begin{array}{l}\text { Gradska knjižnica i } \\
\text { čitaonica „Mladen } \\
\text { Kersner“ }\end{array}$ & $\begin{array}{l}\text { http://www.knjiznica-ludbreg.hr/djecji_odjel/index. } \\
\text { htm }\end{array}$ \\
\hline 10. & $\begin{array}{l}\text { Gradska knjižnica } \\
\text { Slavka Kolara Čazma }\end{array}$ & $\begin{array}{l}\text { http://www.gradska-knjiznica-cazma.hr/index.php/ } \\
\text { za-djecu-i-mladez }\end{array}$ \\
\hline 11. & $\begin{array}{l}\text { Narodna knjižnica } \\
\text { Bjelovar }\end{array}$ & $\begin{array}{l}\text { http://www.knjiznica-bjelovar.hr/index.php/dje- } \\
\text { cji_odjel/ }\end{array}$ \\
\hline 12. & Narodna knjižnica Sisak & http://www.nkc-sisak.hr/odjeli/djecji-odjel/ \\
\hline 13. & $\begin{array}{l}\text { Narodna knjižnica } \\
\text { Kutina }\end{array}$ & https://knjiznica-kutina.hr/odjel-za-djecu-i-mlade/ \\
\hline 14. & $\begin{array}{l}\text { Gradska knjižnica i } \\
\text { čitaonica Vinkovci }\end{array}$ & $\begin{array}{l}\text { http://knjiznice.nsk.hr/vinkovci/moja-knjiznica/top- } \\
\text { 10-djecja-knjiznica-mira/ }\end{array}$ \\
\hline
\end{tabular}




\begin{tabular}{|c|l|l|}
\hline 15. & $\begin{array}{l}\text { Gradska knjižnica } \\
\text { Rijeka }\end{array}$ & $\begin{array}{l}\text { http://gkr.hr/Vodic-za-korisnike/Nasi-programi/ } \\
\text { Za-djecu-i-roditelje }\end{array}$ \\
\hline 16. & $\begin{array}{l}\text { Gradska knjižnica i } \\
\text { čitaonica Pula }\end{array}$ & http://www.gkc-pula.hr/hr/za-djecu-i-mlade/ \\
\hline 17. & $\begin{array}{l}\text { Gradska knjižnica i } \\
\text { citaonica Zadar }\end{array}$ & http://www.gkzd.hr/?q=djecji_preporuke \\
\hline 18. & $\begin{array}{l}\text { Gradska knjižnica } \\
\text { „Juraj Šižgorićc Šibenik }\end{array}$ & http://www.knjiznica-sibenik.hr/ \\
\hline 19. & $\begin{array}{l}\text { Gradska knjižnica } \\
\text { Vodice }\end{array}$ & $\begin{array}{l}\text { http://www.gkv.hr/index.php?option=com_conten- } \\
\text { t\&view=category\&layout=blog\&id=42\&Itemid=358 }\end{array}$ \\
\hline 20. & $\begin{array}{l}\text { Gradska knjižnica } \\
\text { Kaštela }\end{array}$ & http://www.gkk.hr/djeca-i-mladi// \\
\hline 21. & Gradska knjižnica Solin & http://www.knjiznicasolin.hr/index.php/djeciji-odjel \\
\hline 22. & $\begin{array}{l}\text { Pučka knjižnica i } \\
\text { čitaonica Daruvar }\end{array}$ & http://knjiznica-daruvar.hr/djecji-odjel/ \\
\hline 23. & $\begin{array}{l}\text { Gradska knjižnica } \\
\text { „Mato Lovrak“ } \\
\text { Grubišno Polje }\end{array}$ & http://www.gkml.hr/odjeli/djecji-odjel/ \\
\hline 24. & $\begin{array}{l}\text { Gradska knjižnica } \\
\text { Slavonski Brod }\end{array}$ & $\begin{array}{l}\text { http://www.gksb.hr/index.php/odjeli/citaonica-i-dje- } \\
\text { cji-odjel }\end{array}$ \\
\hline 25. & $\begin{array}{l}\text { Gradska knjižnica i } \\
\text { čitaonica Lipik }\end{array}$ & http://www.knjiznica-lipik.hr/odjel-za-djecu/ \\
\hline 26. & $\begin{array}{l}\text { Gradska knjižnica i } \\
\text { čitaonica Požega }\end{array}$ & http://www.gkpz.hr/odjeli/djecji/ \\
\hline 27. & $\begin{array}{l}\text { Gradska knjižnica i } \\
\text { čitaonica Slatina }\end{array}$ & $\begin{array}{l}\text { http://www.knjiznica-slatina.hr/odjeli/odjeli-knjizni- } \\
\text { ce/ }\end{array}$ \\
\hline 28. & $\begin{array}{l}\text { Gradska knjižnica } \\
\text { Valpovo }\end{array}$ & $\begin{array}{l}\text { https://gradskaknjiznicavalpovo.weebly.com/dje- } \\
\text { 269ji-odjel.html }\end{array}$ \\
\hline 29. & $\begin{array}{l}\text { Gradska i sveučilišna } \\
\text { knjižnica Osijek }\end{array}$ & $\begin{array}{l}\text { http://www.gskos.unios.hr/index.php/odjel-za-rad-s- } \\
\text { djecom-i-mladima/ }\end{array}$ \\
\hline 30. & $\begin{array}{l}\text { Gradska knjižnica } \\
\text { Županja }\end{array}$ & https://www.gkzu.hr/knjiznica-za-najmlade \\
\hline 31. & $\begin{array}{l}\text { Gradska knjižnica } \\
\text { Crikvenica }\end{array}$ & $\begin{array}{l}\text { http://www.knjiznica-crikvenica.hr/index.php/dje- } \\
\text { cji-kutak }\end{array}$ \\
\hline 32. & $\begin{array}{l}\text { Gradska knjižnica } \\
\text { Samobor }\end{array}$ & $\begin{array}{l}\text { https://www.samobor.hr/knjiznica/odjel-za-djecu-i- } \\
\text { mlade-c73 }\end{array}$ \\
\hline
\end{tabular}

